\title{
Concentration Analysis of the Hungarian Mangalica Pig Stock
}

\author{
Krisztina Pocsai, Péter Szabó, Péter Balogh \\ University of Debrecen, Debrecen, Hungary
}

\begin{abstract}
In the animal raising sector of Hungary, the indigenious and special Hungarian product called Mangalica pig has a special significance. Some descriptions were made about the species but the concentration of this segment has not been examined, that is why the aim of the researchers is to analyse the concentration of the Mangalica population on the basis of various statistical methods in the last 10 years. The certain concentration indexes were the following: the concentration ratio, the Lorenz-curve, the Gini-coefficient, the Herfindahl-index and the redundancy index. Through the analysis we realised that from 2000 a kind of concentration started, which in case of the concentration ratio, the Lorenz-curve and the Gini-coefficient were in 2001 and 2003 of the highest ratio. The Herfindal-index and redundancy index showed that the years of 2000 and 2002 were the most significant, because of a number of large-scale producers started their activities or developed their stocks in these years. On the basis of the results, it can be stated that in the years before the application and after the recession the concentration of the stock was instable, while at the beginning of the supporting period until the crisis the appearance of large-scale firms became equal but basically according to every index the concentration in the examined years was approximately average.
\end{abstract}

Keywords: concentration indexes, Mangalica pig, stock concentration, Lorenz-curve

\section{Introduction}

The definition of the concentration is different in the distinct areas of science, but its meaning is similar: massing, focusing, merge of something. Both in chemistry, in economics, in medical and psychological literature, it is an often used concept. In statistical meaning, it is known many kinds of definition depending on the available data and the aim of the analysis. The concentration analysis is an often applied method in the agriculture, with which both the Hungarian and the foreign special literature treated for a long time (Jarrett, 1968; Bethlendi \& Kerékgyártó Gy-né, 1970; Hajdu, 1986). The examination of Hungarian agrarian sector is always seasonable, because the national economy importance of the Hungarian agricultural sector according to Kovács’s (2010) establishment is still considerable despite the negative trends of last years. The animal husbandry within the

Krisztina Pocsai, Ph.D. candidate, Faculty of Applied Economics and Rural Development, University of Debrecen.

Péter Szabó, Ph.D., Associate Professor, Faculty of Agricultural and Food Sciences and Environmental Management, University of Debrecen.

Péter Balogh, Ph.D., Associate Professor, Faculty of Applied Economics and Rural Development, University of Debrecen.

Correspondence concerning this article should be addressed to Krisztina Pocsai, University of Debrecen, Debrecen Hungary Böszörményi Str. 138. H-4032. E-mail: pocsaik@agr.unideb.hu. 
pig-breeding represent has an important position in the Hungarian agricultural sector. One of the criteria of the pig-breeding is the stock concentration (Udovecz, 2009). Popp and Nyárs (2009) have written that concentration and fragmentation are tipical of the Hungarian pig sector. The 90 percent of pig-breeder had been keeping less than 10 animals in 2005-2007, and 99 percent had been keeping less than 50 pigs. By statements of Szabó, Balogh, Komlósi, Kusza, Bálint, and Bíró (2009) almost 60 percent of animal stock is found in 1 percent of pig-breeders.

Mangalica pig came to the front again with the continuous change of consumer behaviour, whose role has in earlier years notably increased, it has become increasingly popular to keep indigenous species and increased again the demand for traditional products (Kiss, Vincze, Tenk, Pászthy, \& Tóásó, 2005). In 1991 the establishing of Olmos and Tóth Ltd. kindled interest for the Mangalica as a Hungaricum, with that vertical integration, which perform the Hungarian farmers and the ham factory of Jamones Segovia Sa in Spain in Carbonero el Mayor. The National Association of Mangalica Breeders (NAMB) was reorganized in 1994, as a consequence of it, that breeding and products of by 1991 almost died out species reported new market demands. As a result it increased the breeding mood and the less than 200 animals counting stock started to growing dynamically (Magyar, 2005).

The importance of the theme is that the concentration of Mangalica sector-as an independent animal-husbandry sector - has not been analysed, for all that it would be a breaking point for the Hungarian agriculture. In consideration of all sector and department in the world, e.g., industry, trade, agriculture or demography - are in progress significant concentration processes. Because of this we feel it is necessary to find on the basis of available data, that in this little segment happened similar processes. The analysis didn't perform worthy back for several decades, because from the Second World War to the period before 2000 wasn't substantial the Hungarian Mangalica pig stock, but from the millenium the number of pedigre stock started continuously increase, so we performed our measuring from this period.

\section{Materials and Methods}

In our study, we analysed the concentration of Mangalica stock the National Association of Mangalica Breeders (NAMB) collected by national database between the years of 2000 and 2009. The data in regard to the stock and the breeds were available for us according to farm size. The measuring were performed by different statistical methods, which were the concentration ratio (CR), the Lorenz-curve, the Gini-coefficient, the Herfindahl-index and the redundancy index. These indexes are the generally used and accepted in the economy, this is why we consider to present and interpret of this measuring's importance. The special literature mentions many kinds of concentration-analysis methods (Hubbell \& Welsh, 1998; El-Osta \& Morehart, 2002; Crespi \& Marette, 2006; Mitton, 2008), which are used often in agriculture.

The Lorenz-curve and the Gini-coefficient are in close connection with each other, because the Gini-coefficient means the ratio of the area between the diagonal and the Lorenz-curve over the triangular area under the diagonal (Riemenschneider, 1976). The formula is:

$$
G=\frac{1}{2 \bar{x} n^{2}} \sum_{i} \sum_{j}\left|x_{i}-x_{j}\right|
$$


where: $x_{i}, x_{j}=$ feature as distribution ratio in the $i$ th and $j$ th number category; $\bar{x}=$ the mean of $x_{i} ; n=$ the total number of farms. The Gini-coefficient ranges between 0 and 1 . According to the United Nations methodology (Nyárs, 2005) we can speak, if:

- Gini > 0.90: very high concentration;

- $0.90>$ Gini > 0.60: high concentration;

- $0.60>$ Gini > 0.40: moderate concentration;

- $0.40>$ Gini > 0.30: low concentration;

- Gini < 0.30: very low concentration.

One of the most widely accepted and common used concentration index is the Herfindahl-index (Mitton, 2008). The maximum value is 1 , which means the total concentration (Jaud, Cadot, \& Eisenmann, 2009). Its measuring is the following:

$$
H I=\sum_{i=1}^{N}\left(\frac{x_{i}}{s}\right)^{2}=\sum Z^{2}
$$

where: $x i=$ the sow number of the $i$ th number category; $s=$ the total number of sows. To determine whether an agricultural sector is concentrated, the Herfindahl-index gives following guidance:

$\mathrm{HI}>0.18$ : concentartion is high;

$0.1<\mathrm{H}<0.18$ : concentration is moderate;

$\mathrm{HI}<0.1$ : concentartion is low (Blank \& Persson, 2004).

The redundancy inequality index is derived from the entropy, and it measures the inequality in the distribution structure of criterion values. Complete equality occurs when $R_{\mathrm{z}}=\log N$. Its formula is (Hart, 1971):

$$
H I=\sum_{i=1}^{N}\left(\frac{x_{i}}{s}\right)^{2}=\sum Z^{2}
$$

\section{Results and Findings}

\section{General Sectoral Description}

The Mangalica not only in Hungary but also in other countries can be found, however it is just in our country indigenous species. In Austria, there are 70 breeders, who keep about 300 sows and there is not one, who has more than 50 animals, therefore we can't talk about high production. In Switzerland, similarly to Austria, there are about 300 registered sows, where is breeding organization of the sector too. There can be found mostly swallow-bellied variety of the Mangalica pig. In ours neighbouring countries, like in Serbia, in Romania and in Slovakia - mainly in beyond the frontier with Hungarian population areas - there are altogether maximum 1,000 breeding animals, which is 10-15 percent of native numbers. Europe attend the Managlica as product in Spain, where produces the world-famous Serrano ham. Beyond the sea is bred, in America there are about 1,000 Mangalica, which products are served mainly in elegant restaurants. The largest importer is Japan from Mangalica, whose market claim Hungary unfortunately can’t fulfil for the present.

In the first six years of the period under survey the stock grown more than fivefold and attained almost 9,000 animals, with the Managlica market culminated. This sow-number resulted in 60,000-80,000 Mangalica pigs for 
slaughter each year. The increase of market demand was not proportional to growth of pedigree stock. The oversupply kept back the prices and by means of decrease of profitability influenced unfavourably the productivity. Since 2005 ensued a strong climbing in the Mangalica sector, whose reason was the target program for the keeping of animals representing a high genetical value which are indigenous (MRD, 2004). The subvention was in force to 2009, after all from the third year of the application continuous decline can we observe, that was attributed to drastic increase of feed costs. Because of this and the effect of global economic crisis a lot of farmer constrained to stopp the breeding and liquidat the livestock. The price of corn and wheat approached 60,000 HUF per ton, which the concentrate fed pig, especially the Mangalica couldn't tolerate.

Examining the data of the national average sow mild fluctuation can be observed in some years, the average sow number was the least in 2003 (39 animals), but in 2007 was the highest (56 animals). For the first year of the analysis the average sow-number was 41, that was only less than in two years, in 2001 and 2003. Contrary to all of the amount of pedigree stock, in the average sow-number was the largest rate of growth from 2005 to 2006, about 13 percent, that remained stable still the year after. In 2008 ensued a considerable decline, it is expressly due to that the enterprises couldn't cover the disbursements no longer, the economic crisis marked with theirs activity and several farmers quitted the market. As the breeders increased the number of farmers engaged in Managlica from the early 40 animals to 168 in 2006, it represents more than fourfold gain (see Figure 1).

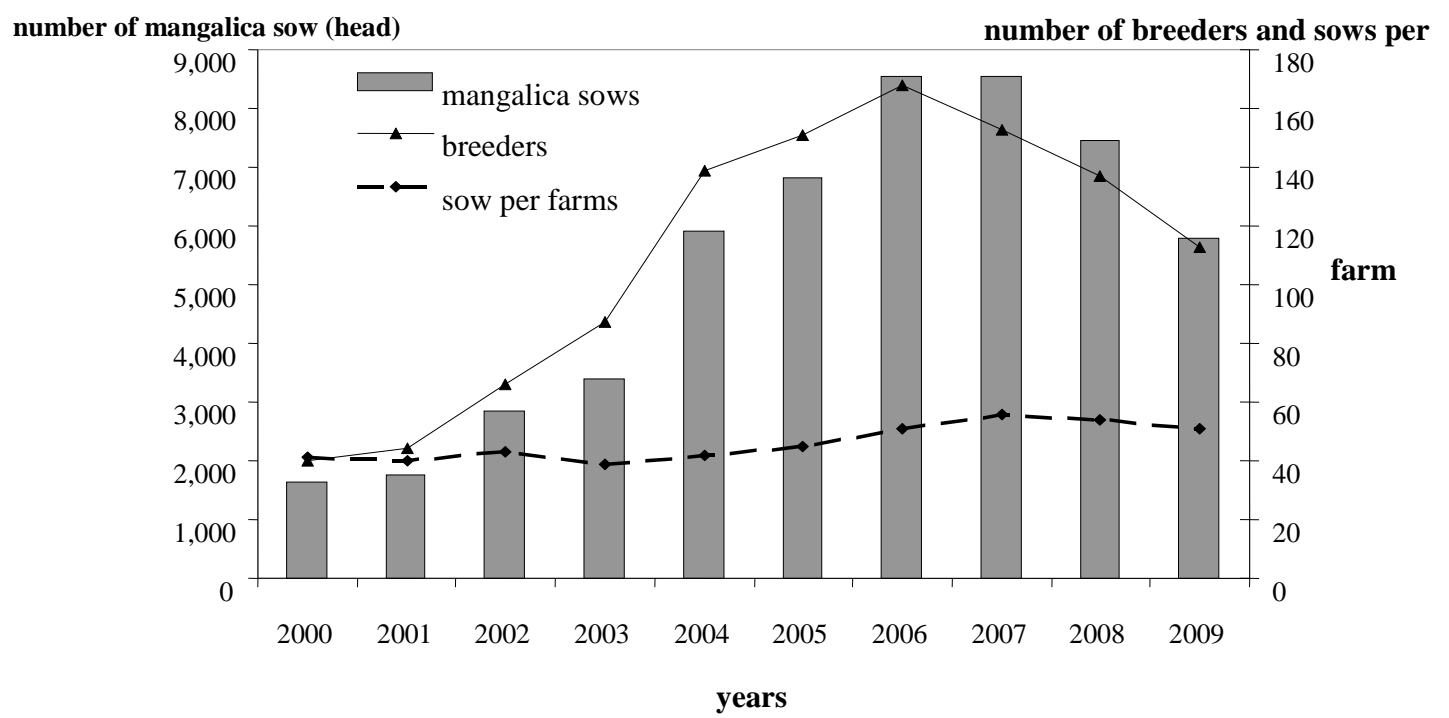

Figure 1. The Mangalica pig sow stock, the average sow number per one farm and the number of breeders. Source: Own calculation on the basis of NAMB's data (2011).

Hungary's total number of breeding animals and the breeds are shown quite fluctuation from year to year. For the year of EU accession (2004) about 70 percent rise has happened in the number of livestock compared to the previous year. The farmers trust in EU's subventions have increased their stock and at the same time the number of farms has grown proportionately. Till 2004 was almost the same their ratio compared the year 2000, then after the application period was the increase of the breeds larger than the stock. This expansion stopped to 2007, although after this it was still three-, four-fold of the 2000 year data. Similar products can be found, if we look at the chain relative, that 2007 was the year, when the number of sows and the farms were less than the previous year (see Figure 2). As regards of the chain and the base relatives it is perceptible the effect of the crisis, 
after 2007 it can be observed decline every year. But in that year, the recession of the number of breeders was a larger extent, then from 2008 the sow-stock decreased a larger measure.

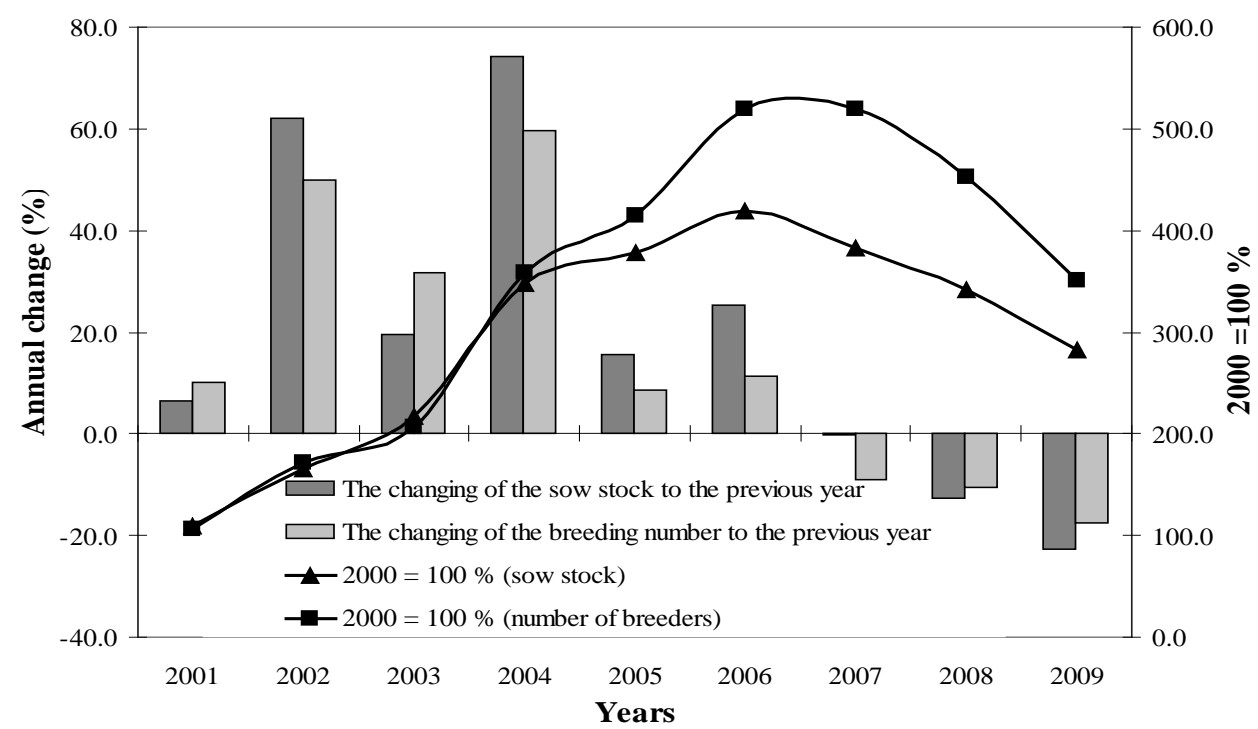

Figure 2. The change of sow stock and the number of breeders in 2000-2009. Source: Own calculation on the basis of NAMB's data (2011).

\section{The Results of Concentration Analysis}

A high degree of fragmentation was characteristic of the operating structure still in 2000, because the rate of farms below 50 sows was nearly 80 percent of the total within the breed, but they possessed only 33 percent of the total livestock. As opposed to it the farms with 101-250 sows kept more than half of the stock. In that year we couldn't speak really large farms in this sector, farms over 250 sows resided in 2005 almost 3 percent, who held 20 percent of the total stock. This time begins a significant concentration in the Mangalica breeding, that resulted in a drastic decrease of the small farms and the proportion of there kept pigs, but because of application of tending to indigenous species subvention increased the breeding behalf and entered some large farmers to the production. The number of small-scale producers reduced to almost 30 percent in a short time, and 60 percent of the largest stock farms (300-500 sows) finished the production in 2009 (see Table 1). From 2010, t began new chronology in the farmers, who keep indigenous animals, because it began further subventional period, which will hold to December 31, 2014. The aim is the subvention to conservation and keeping in breeding the genetic stock of protected indigenous and endangered agricultural species with low number (MRD, 2010). This program has stopped the decline, and even to the end of the application period, there assumed more than half of the farmers 50 percent growth in the sow number.

According to Nyárs's (2005) establishment, which describe the animal husbandry sectors considerable inequality, the result can be the strengthening concentration. One of the simplest measuring methods of the concentration analysis is the concentration ratio (CR), because of the simple data demand and the easy interpretation one of the most often used methodology. The CR gives a reference of the advantaged part of the distribution, the higher pole, it focuses on the largest farms, doesn't describe the total population. On the basis of Table 2, it can be told that observely, the CR-s have happened a slight concentration in the ratio of Mangalica number, and in 2003, it was the largest one. In case of $m=1$ we have considered the stock ratio of the largest 
farm, by $m=2$ the amount of the first two largest farms ratio, and by $m=3$ the first three largest farms. It seems good, that it was the slightest the value of this index in each three case in 2000, so in that year the number of large farms has been low. However in 2003, the large farms held 43 percent of the total livestock. In the following years the large farm's share was even lower, and the sow number didn't increase considerably by the farms over 150 sows after the application.

Table 1

The Distribution of the Breeder and the Number of Livestock in 2000-2009

\begin{tabular}{|c|c|c|c|c|c|c|c|c|c|}
\hline & \multicolumn{9}{|c|}{ The Mangalica pig stock measure categories (number) } \\
\hline & $1-20$ & $21-30$ & $31-50$ & $51-80$ & $81-100$ & $101-150$ & $151-250$ & $251-400$ & $401-600$ \\
\hline & \multicolumn{9}{|c|}{ Distribution of number of breeders every year (\%) } \\
\hline 2000 & 50 & 15 & 12,5 & 7.5 & 0 & 10 & 5 & 0 & 0 \\
\hline 2001 & 47.7 & 18.2 & 15.9 & 6.8 & 2.3 & 4.5 & 2.3 & 2.3 & 0 \\
\hline 2002 & 40.9 & 22.7 & 15.2 & 7.6 & 1.5 & 4.5 & 7.6 & 0 & 0 \\
\hline 2003 & 49.4 & 24.1 & 13.8 & 2.3 & 0 & 3.4 & 4.6 & 2.3 & 0 \\
\hline 2004 & 36.7 & 26.6 & 16.5 & 7.2 & 3.6 & 5.0 & 2.2 & 2.2 & 0 \\
\hline 2005 & 34.4 & 25.8 & 18.5 & 10.6 & 0.7 & 5.3 & 2.0 & 2.0 & 0.7 \\
\hline 2006 & 26.8 & 28.6 & 16.7 & 13.7 & 2.4 & 6.0 & 3.6 & 1.8 & 0.6 \\
\hline 2007 & 23.5 & 27.5 & 19.6 & 11.1 & 4.6 & 5.9 & 5.2 & 2.0 & 0.7 \\
\hline 2008 & 12.4 & 41.6 & 22.6 & 6.6 & 6.6 & 2.9 & 5.1 & 0.7 & 1.5 \\
\hline \multirow[t]{2}{*}{2009} & 15.0 & 43.4 & 21.2 & 4.4 & 7.1 & 2.7 & 4.4 & 0 & 1.8 \\
\hline & \multicolumn{9}{|c|}{ Distribution of Mangalica pig stock every year (\%) } \\
\hline 2000 & 12.2 & 9.1 & 12.2 & 11.9 & 0 & 30.4 & 24.3 & 0 & 0 \\
\hline 2001 & 12.0 & 11.4 & 16.0 & 11.1 & 5.1 & 14.3 & 11.4 & 18.6 & 0 \\
\hline 2002 & 9.5 & 13.2 & 14.1 & 11.5 & 3.2 & 13.2 & 35.3 & 0 & 0 \\
\hline 2003 & 12.7 & 15.5 & 14.2 & 3.8 & 0 & 11.1 & 23.6 & 19.2 & 0 \\
\hline 2004 & 8.6 & 15.7 & 15.6 & 11.0 & 7.6 & 14.8 & 10.2 & 16.5 & 0 \\
\hline 2005 & 7.6 & 14.3 & 16.4 & 15.2 & 1.3 & 14.7 & 8.8 & 14.3 & 7.3 \\
\hline 2006 & 5.3 & 14.0 & 13.1 & 17.5 & 4.2 & 14.6 & 14.0 & 11.4 & 5.8 \\
\hline 2007 & 4.2 & 12.3 & 14.0 & 12.9 & 7.4 & 13.2 & 18.7 & 11.4 & 5.9 \\
\hline 2008 & 2.3 & 19.1 & 16.6 & 7.8 & 10.9 & 6.7 & 18.8 & 4.4 & 13.4 \\
\hline 2009 & 2.9 & 21.2 & 16.6 & 5.6 & 12.5 & 6.5 & 17.3 & 0 & 17.3 \\
\hline
\end{tabular}

Table 2

The Concentration Ratio (CR) in 2000-2009

\begin{tabular}{llcc}
\hline & $>150$ sows/farm $(m=3)$ & $>250$ sows/farm $(m=2)$ & $>400$ sows/farm $(m=1)$ \\
\hline 2000 & 24.3 & 0.0 & 0.0 \\
2001 & 30.0 & 18.6 & 0.0 \\
2002 & 35.3 & 0.0 & 0.0 \\
2003 & 42.8 & 19.2 & 0.0 \\
2004 & 26.7 & 16.5 & 0.0 \\
2005 & 30.4 & 21.6 & 7.3 \\
2006 & 31.3 & 17.3 & 5.8 \\
2007 & 36.0 & 17.3 & 5.9 \\
2008 & 36.6 & 17.8 & 13.4 \\
2009 & 34.6 & 17.3 & 17.3 \\
\hline
\end{tabular}


The stock concentration is most illustrated by the Lorenz-curve. The horizontal axis of the curve shows the cumulative relative frequency of breeders, the vertical axis shows the cumulative sum of the values of the Mangalica sowstock. The analysis applies to the period between 2000-2009. The following figure is presented the four years data, because 2005 was the first year of the application, so we devided the examination into two parts. The first part was the period before the subvention, the second was after it. We supposed that the granted subvention influenced the breeding behalf and with it the stock concentration. The diagonal line, or the egalitarian line represents the perfect equality in the unit square. If the curve coincides with this line, it means that each breeder keeps the same livestock, which is the case of the perfect equality. In the case of perfect inequality of the stock, the Lorenz-curve coincides with the sides of the square, which implies that all animal is bred by only one farmer. It follows from this that the growing of the space between the line and the curve announces high-class stock concentration.

It can be seen from Figure 3 that in each year it had a moderate concentration, but there are little differences. In the first year of the analysis the 70 percent of the farmers owned the quarter of the total Mangalica number. This ratio changed below 3 years, that the 80 percent of the farms held about third part of the total livestock. That shows the halfway point, which can be read about the line touching the Lorenz-curve paralell with the diagonal. In that year, there was the curve - the nearest to the side of the square - that means at that time, it was the largest concentration. The cause of it is that the large farmers entry and the number of the small-scale producers declined. It can be proved that it reduced from 2003 to the first year of the subvention, in the concentration area, so the number of the large-breeders slightly slowed down.

After the application it can be told clearly from the figure that the breeding behalf has increased and the headway of the small-scale farms has been the typical. The reason for this was, that in 2009-in the first quarter of the square- the concentration curve moved away from the curves of the earlier years and it stayed above the curve of the 2005. The large-scale farms owned still significant volume of the livestock, for all that several breeders stopped their activity on the effect of the global economic crisis and the drought damage in 2007. It can be satisfied as to the facts that the analysis the past years in 2009 was the concentration and the slightest one in the sector, which represents the concentration area.
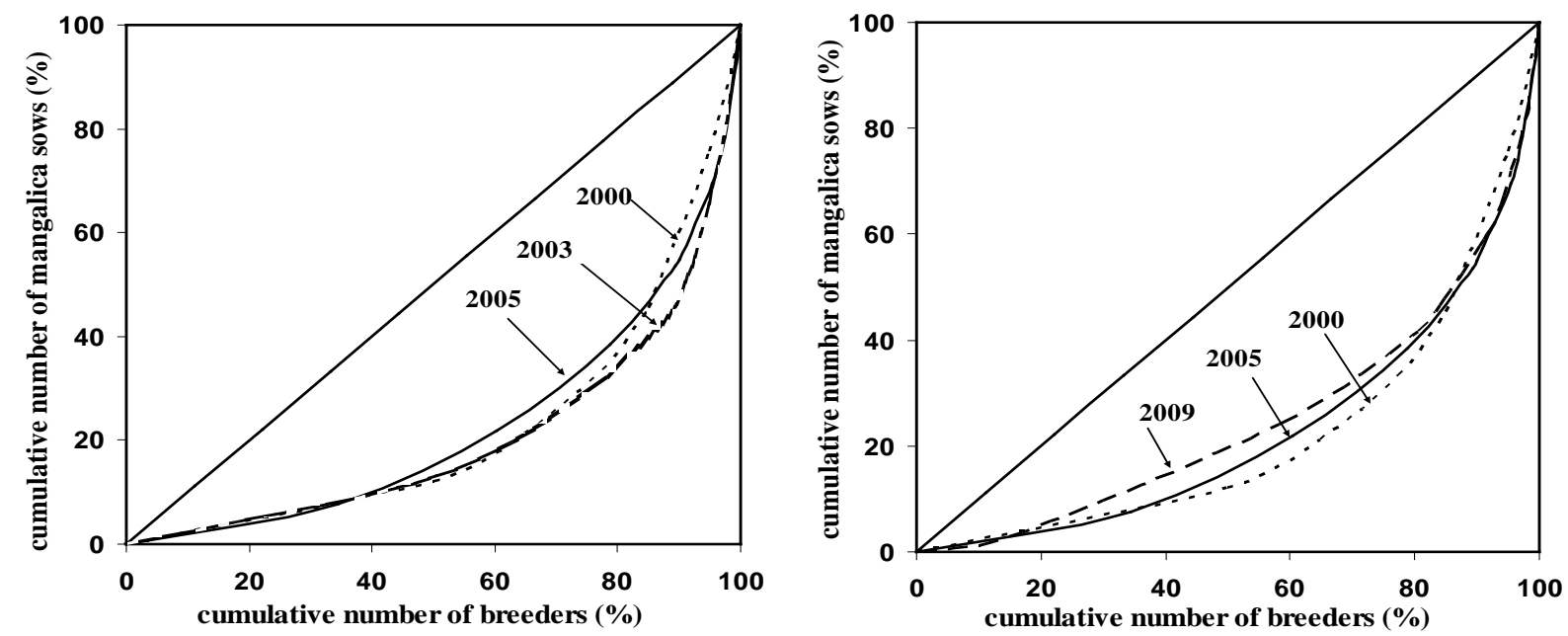

Figure 3. The Lorenz-curves in the four significant years. Source: Own calculations (2011). 
These results are supported by the values of Gini-coefficient, because if the index is $G=1$, then the livestock and the production will concentrate by one farmer, but if $G=0$ the production will distribute equal among the farms. The results show that the stock concentration was the highest in 2001 and 2003, but the lowest was in 2008. The reason of it was the global economic crisis, when some farmers contended with liquidity problems, that's why they are liquidated their agricultural holdings. In the other years it can be seen different fluctuations, after all it is worth to observe that in the period under survey the value of the coefficient changed between 0.49 and 0.58 (see Figure 4). Similarly to the Lorenz curve it can be proved that the concentration was moderate considering the results of the Gini-coefficient.
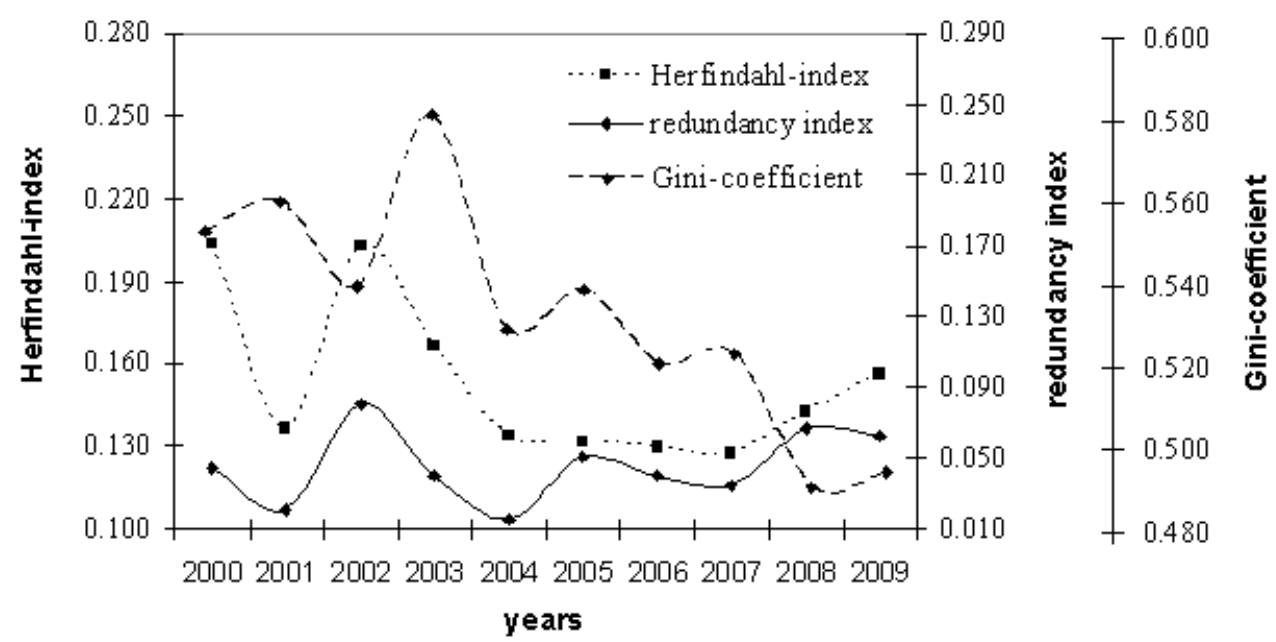

Figure 4. The values of Herfindahl-, the redundancy- and Gini indexes in 2000-2009. Source: Own calculations (2011).

The previously mentioned Herfindahl- (HI) and the redundancy-index are suitable for the measuring of the stock concentration. On the basis of the HI-index's classification the Mangalica stock concentration can be considered moderate every year, except the years of 2000 and 2002, when the index passed the value of 0.2. It means that it was the concentration high in the sector. It can be stated moreover that from 2004 to 2007, the beginning period of the application the verticum was stable, but from 2007 it has an increase again. The cause of it was that the previously mentioned corn price is risen and at the same time the farms was liquidated. The redundancy index shows a similar tendency to the HI-index, as it increases its value, it also increases the concentration. Before the subvention the process was broken in two cases, in 2001 and 2004, thereafter it followed the earlier described.

\section{Conclusions}

In the examined period, we could see three sharply devided periods: the years before 2005, years after 2005 until the beginning of the worldwide economic crisis and the years from the crisis until now. The year of 2005 was a turning point in the lives of producers since in the year the target program for the keeping of animals represents a high genetical value and being indigenous. From this year the mood for keeping animals has raised and more and more producers appeared on the market. 
Through the analysis we realised that from 2000 a kind of concentration started, which in case of the concentration ratio, the Lorenz-curve and the Gini-coefficient was in 2001 and 2003 of the highest ratio. The Herfindal-index and redundancy index showed that the years of 2000 and 2002 were the most significant, because these indexes are sensitive to the largest farms. These results are thanks to the fact that a number of large-scale producers started their activites or developed their stocks in these years. In the period after the support the number of animals reached the peak, and at the same time, the ratio of large farms was gradually decreasing. This recession took place as a result of the effects of the sharp increase of feeding cost in 2008 and mainly of the global economic crisis starting simultaniously. The economic crisis had a significant effect on the farmers (small and large at the same time) selling off their farms and only the mid-sized farms kept their production, because they had other activities, so they remained stable financially.

It can be observe from the results that in the Mangalica pig breeding didn't happen similar processes like in other department in the world, because of the speciality of this segment.

In regard to the future based on past experiences an increases is expected due to the following application period, that we hope will not prevent a further rise of the feed price or an another recession.

\section{References}

Bethlendi, L., \& Kerékgyártó, Gy-né. (1970). Koncentráció és hatékonyság az állami gazdaságokban. Statisztikai Szemle, 48, 649-658.

Blank, M., \& Persson, A. M. (2004). The Swedish food retail market. An econometric analysis of the competition on local food retail markets. Retrieved from http://www.diva-portal.org/liu/abstract.xsql?dbid=2521

Crespi, J. M., \& Marette, S. (2006). Quality and competition: an empirical analysis across industries. Working paper 06-WP 420 Center for Agricultural and Rural Development, Iowa State University.

El-Osta, H. S., \& Morehart, M. J. (2002). The dynamics of wealth concentration among farm operator households. Agricultural and Resource Economics Review, 31(1), 84-96.

Hajdu, O. (1986). A beruházások koncentrációjának vizsgálata. Statisztikai Szemle, 64(3), 234-260.

Hart, P. E. (1971). Entropy and other measures of concentration. Journal of the Royal Statistical Society. Series A (General), 134(1), 73-85.

Hubbell, B. J., \& Welsh, R. (1998). An examination of trends in geographic concentration in U.S. hog production, 1974-1996. Journal of Agricultural and Applied Economics, 30, 285-299.

Jarrett, F. G. (1968). On the growth of the agricultural firm. The Australian Journal of Agricultural Economics, $12(2), 15$.

Jaud, M., Cadot, O., \& Eisenmann, A. S. (2009). Do food scares explain supplier concentration? An analysis of EU agri-food imports. Working paper. Paris School of Economics.

Kiss, Cs., Vincze, J., Tenk, A., Pászthy, Gy., \& Tóásó, Sz. (2005). Fogyasztói vélemények a bio-sertéshúsról, illetve a sertéshúsfogyasztásról. Gazdálkodás, 49(6), 26-32.

Kovács, G. (2010). A mezőgazdasági szektor nemzetgazdasági jelentősége. Gazdálkodás, 54(5), 466-478.

Magyar, K. (2005). A Mangalica, mint hungarikum. Östermelö, gazdálkodók lapja, 9(3), 78.

Mitton, T. (2008). Institutions and concentration. Journal of Development Economics, 86, 367-394.

MRD (Ministry of Rural Development). (2004). 150/2004. (X. 12.) FVM rendelet a Nemzeti Vidékfejlesztési Terv alapján a központi költségvetés, valamint az Európai Mezőgazdasági Orientációs és Garancia Alap Garancia Részlege társfinanszírozásában megvalósuló agrár-környezetgazdálkodási támogatások igénybevételének részletes szabályairól. Magyar Közlöny, 12(146), 12011-12134.

MRD (Ministry of Rural Development). (2010). 38/2010. (IV. 15.) FVM rendelet az Európai Mezőgazdasági Vidékfejlesztési Alapból a védett őshonos és a veszélyeztetett mezőgazdasági állatfajták genetikai állományának tenyésztésben történő megőrzésére nyújtandó támogatások részletes feltételeiről. Magyar Közlöny, 15(54), 12822-12854.

NAMB (National Association of Mangalica Breeders). (2010). Registers of the registered breeders.

Nyárs, L. (2005). A magyar sertéshústermelés gazdasági környezetének vizsgálata (Ph.D. thesis, Gödöllő). 
Popp, J., \& Nyárs, L. (2009). A sertéshús-feldolgozás versenyképessége Magyarországon. A hús, 19(1-2), 48-54.

Riemenschneider, C. H. (1976). The use of the Gini ratio in measuring distributional impacts. A Research Report Submitted to Michigan State in partial fulfillment of the requirements for the degree of Master of Science. Department of Agricultural Economics, 35. Retrieved from http://ageconsearch.umn.edu/bitstream/11118/1/pb76ri01.pdf

Szabó, P., Balogh, P., Komlósi, I., Kusza, Sz., Bálint, A., \& Bíró, T. (2009). Debreceni álláspont. A sertéstenyésztés jövőjéről. In: J. Nagy, \& A. Jávor (Eds.), Debreceni álláspont az agrárium jelenéröl, jövőjéröl (pp. 325-346). Magyar Mezőgazdaság Kft. Budapest.

Udovecz, G. (2009). A sertéságazat versenyképessége Magyarországon. A hús, 19(1-2), 44-47. 